Sains Malaysiana 49(5)(2020): 1115-1120

http://dx.doi.org/10.17576/jsm-2020-4905-16

\title{
Correlation between Alberta Stroke Programme Early Computed Tomography Score (ASPECTS) and National Institute of Health Stroke Score (NIHSS) in Ischemic Stroke
}

(Korelasi antara Skor Awal Tomografi Berkomputer Program Strok Alberta (ASPECTS) dan Skor Strok Institut Kesihatan Nasional (NIHSS) pada Strok Iskemik)

\author{
Lisda Amalia*, MARda ARIF FurqANi, IDA PARWATI, AHMAD RiZAL \& RAMDAN PANigoro
}

\begin{abstract}
Computed tomography scanning (CT-scan) hold an important role in diagnosing ischemic stroke, but may find difficulties to assess an early ischemic changes. ASPECTS provide a tool for assessing CT-scan in ischemic stroke, which can be used as predictor of stroke outcome. Stroke outcome and severity can also be assessed using NIHSS. We hypothesize that ASPECT score had negative correlation with neurological deficit in patient with acute ischemic stroke compared with non-contrast head CT scan. This was an analytic-descriptive cross-sectional study on firstonset ischemic stroke patient in Neurology Ward of Hasan Sadikin General Hospital admitted from October 2017 - February 2018. ASPECTS was calculated from CT-scan of ischemic stroke patients involving medial cerebral artery and compared to NIHSS. From 58 subject (44.8\% male, 55.2\%) female), with mean age $56.60 \pm 9.1$ years, there were $58.6 \%$ subject with lacunar stroke, 20.7\% with large artery atherosclerotic (LAA) stroke, and 20.7\% with cardioemboli stroke. Subjects with LAA stroke and lacunar stroke had higher ASPECTS ( $p$ value $<0.05)$ and had lower NIHSS ( $p$ value $<0.05)$ than subjects with cardioembolic stroke. Spearman's correlation test between ASPECTS and NIHSS show a strong correlation between ASPECTS and NIHSS $(r=-0.680, p<0.001)$. There was a strong inverse correlation between ASPECTS and NIHSS score on acute ischemic stroke. The higher the value of ASPECTS, the lower the value will be for NIHSS and ASPECT score had correlation with stroke severity.
\end{abstract}

Keywords: ASPECTS; ischemic stroke; NIHSS

ABSTRAK

Pengimbasan tomografi berkomputer (skan CT) memainkan peranan penting dalam mendiagnosis strok iskemia, tetapi mungkin menghadapi kesukaran untuk menilai perubahan awal iskemia. ASPECTS menyediakan alat untuk menilai skan CT pada strok iskemia, yang boleh digunakan sebagai peramal kesan strok. Kesan dan keparahan strok juga dapat dinilai menggunakan NIHSS. Kami membuat hipotesis bahawa skor ASPECT mempunyai korelasi negatif dengan defisit neurologi pada pesakit dengan strok iskemia akut berbanding dengan skan CT kepala tanpa kontras. Ini adalah kajian keratan rentas analitik-deskriptif pada pesakit strok iskemia pertama di Wad Neurologi Hospital Umum Hasan Sadikin yang diterima dari Oktober 2017 - Februari 2018. ASPECTS dihitung daripada skan CT pesakit strok iskemia yang melibatkan arteri serebrum medial dan dibandingkan kepada NIHSS. Daripada 58 subjek (44.8\% lelaki, 55.2\%) wanita), dengan min usia 56.60+ 9.1 tahun, terdapat 58.6\% subjek dengan strok lakunar, 20.7\% dengan strok aterosklerotik arteri besar (LAA) dan 20.7\% dengan strok kardioemboli. Subjek dengan strok LAA dan lakunar mempunyai ASPECTS yang lebih tinggi (nilai $p<0,05)$ dan mempunyai NIHSS yang lebih rendah (nilai $p<0,05$ ) daripada subjek dengan strok kardioemboli. Ujian korelasi Spearman antara ASPECTS dan NIHSS menunjukkan korelasi yang kuat antara ASPECTS dan NIHSS $(r=-0.680, p<0.001)$. Terdapat korelasi berbalik yang kuat antara skor ASPECTS dan NIHSS pada strok iskemia akut. Semakin tinggi nilai ASPECTS, semakin rendah nilainya untuk NIHSS dan skor ASPECT mempunyai hubungan dengan keparahan strok.

Kata kunci: ASPECTS; NIHSS; strok iskemia

\section{INTRODUCTION}

River A stroke is a medical emergency. About 80 percent of strokes are ischemic strokes. Ischemic strokes occur when the arteries to your brain become narrowed or blocked, causing severely reduced blood flow (ischemia). Ischemic strokes occur as a result of an obstruction within a blood vessel supplying blood to the brain. Prompt treatment is crucial. Early action can minimize brain 
damage and potential complications (Alfa 2010; Hacke et al. 2004; Hill et al. 2005; Menon et al. 2011).

Imaging plays a key role in the management of acute ischemic stroke (AIS). Computed tomography (CT) is presently the imaging modality of choice for the evaluation of patients with AIS (Alfa 2010; Hacke et al. 2004; Hill et al. 2005; Menon et al. 2011).

The Alberta Stroke Programme Early CT Score (ASPECTS) is a simple and reproducible grading system developed to assess early ischemic changes in non-contrast computed tomography (NCCT) (Alfa 2010; Meschia et al. 2014; Puetz et al. 2009) and is currently used worldwide in the decision algorithm for thrombolysis and mechanical thrombectomy in anterior circulation AIS (Mansour OY et al. 2015).

Alberta Stroke Programme Early Computed Tomography (ASPECT) score is 10 point scale that's grades early ischemic changes within middle cerebral artery (MCA) territory seen on head CT in patients with acute ischemic stroke (Figure 1). ASPECT is reproducible clinical scale for rating early ischemic changes on $\mathrm{CT}$ that has demonstrated reliability between real time and expert ratings (Mansour et al. 2015).

National Institute of Health Stroke Score (NIHSS) were a tools that can examine neurological deficit in patients with acute stroke. NIHSS can predict clinical outcome on stroke patients. Increasing 1 point of NIHSS can decrease about $28 \%$ of clinical outcome in patient with acute stroke (Mansour et al. 2015; Meschia et al. 2014).

We hypothesize that ASPECT score had negative correlation with neurological deficit in patient with acute ischemic stroke compared with non-contrast head CT scan.
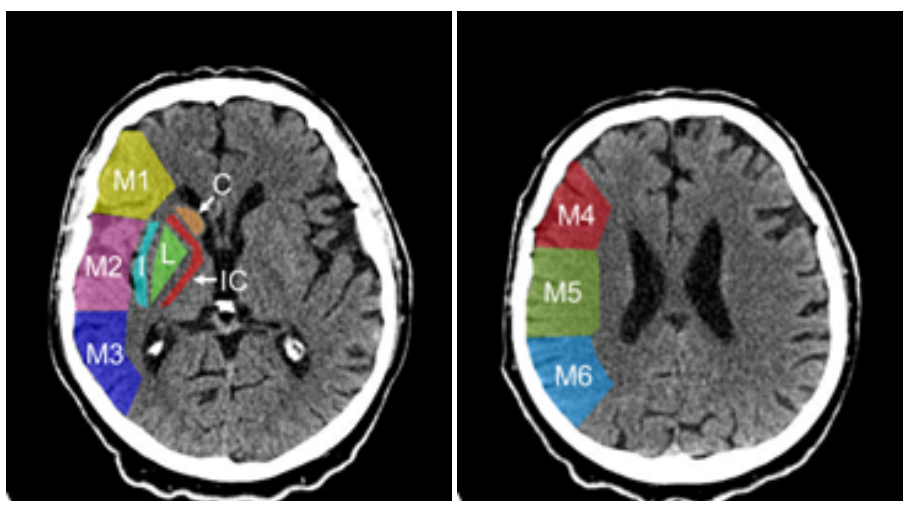

FIGURE 1. Skematic ASPECT on head CT scan5

\section{MATERIALS AND METHODS}

This was a cross sectional study that all anterior ischemic stroke patients from October 2017 until February 2018 which had perform expertise non-contrast head CT scan by radiologist. We excluded ischemic stroke patients with underlying systemic disease that involved level of conciousness and recurrent stroke event.

Stroke classification using Trial of Org 10172 in Acute Stroke Treatment (TOAST) which are large artery atherosclerotic stroke (LAA), lacunar stroke, cardioembolic stroke, other demonstrated cause stroke, and undetermined cause stroke.

ASPECTS was calculated from CT-scan of patients with ischemic stroke involving medial cerebral artery and compared to NIHSS. We divided ASPECT in 2 categories, ASPECT $\leq 7$ and ASPECT 8-10. NIHSS determined on early hospital admission.
Statistics was calculated with Kruskal-Wallis and Spearman rank test using IBM SPSS Statistics for Windows, version 25.0 (IBM Corp., Armonk, N.Y., USA). $\mathrm{p}<0.05$ was considered statistically significance, $\mathrm{r}$ squared is calculated for correlation.

\section{RESULTS}

From 58 subject $(44,8 \%$ male, 55,2\%) female),

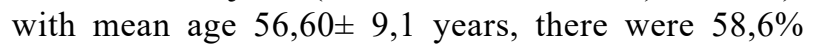
subject with lacunar stroke, $20,7 \%$ with large artery atherosclerotic (LAA) stroke, and 20,7\% with cardioemboli stroke. There were $29.3 \%$ subjects had ASPECTS $\leq 7$ and 70.7\% subjects had ASPECTS $\geq 8$. Mild neurological deficit (NIHSS < 5) were in $19.0 \%$ patients, $60.3 \%$ patients with moderate neuroligical deficit (NIHSS 5-14), and severe neurological deficit (NIHSS $15-25$ ) were in $20.7 \%$ subjects (Table 1 ). 
TABLE 1. Characteristic data of stroke patients $(n=58)$

\begin{tabular}{|c|c|}
\hline Variable & $\mathrm{n}(\%)$ \\
\hline \multicolumn{2}{|l|}{ Age $($ mean \pm SD) } \\
\hline - year & $56.6 \pm 9.1$ \\
\hline \multicolumn{2}{|l|}{ Sex, n (\%) } \\
\hline - Male & $26(44.8)$ \\
\hline - Female & $32(55.2)$ \\
\hline \multicolumn{2}{|l|}{ Stroke type } \\
\hline - Large artery atherosclerotic & $12(20.7)$ \\
\hline - Lacunar stroke & $34(58.6)$ \\
\hline - Cardioembolic & $12(20.7)$ \\
\hline \multicolumn{2}{|l|}{ Onset, n(\%) } \\
\hline - Early hyperacute $(<3 \mathrm{~h})$ & $3(5.2)$ \\
\hline - hyperacute (3-6 h) & $6(10.3)$ \\
\hline - Acute $(6-24$ h) & $28(48.3)$ \\
\hline - Subacute (1-21 h) & $21(36.2)$ \\
\hline - Chronic $(>21 \mathrm{~h})$ & 0 \\
\hline \multicolumn{2}{|l|}{ ASPECT score } \\
\hline - Score $\leq 7$ & $17(29.3)$ \\
\hline - Score 8-10 & $41(70.7)$ \\
\hline \multicolumn{2}{|l|}{ NIHSS } \\
\hline - Mild neurological deficit (0-4) & $11(19.0)$ \\
\hline - Moderate neurological deficit (5-14) & $35(60.3)$ \\
\hline - Severe neurological deficit (15-25) & $12(20.7)$ \\
\hline - Very severe neurological deficit $(>25)$ & 0 \\
\hline
\end{tabular}

ASPECT ANALYSIS ACCORDING TO STROKE SUBTYPE From 58 subjects, we got mean ASPECTS $7.8 \pm 2.2$ and median score 9. Subjects with LAA stroke and lacunar stroke have higher ASPECTS ( $\mathrm{p}$ value $<0.05$ ) than cardioembolic stroke (Figure 2).

\section{ANALYSIS NIHSS ACCORDING TO STROKE SUBTYPE} From 58 subjects, we got NIHSS 2 until 24 with mean score $9.7 \pm 5.9$. Subjects with LAA stroke and lacunar stroke have lower NIHSS ( $\mathrm{p}$ value $<0.05$ ) than subjects with cardioembolic stroke (Figure 2).

After analyzing with Spearman correlation test between ASPECT and NIHSS score, we found that coefficient Spearman correlation -0.680 which were had strong negative correlation between two variables (Figure 3). 


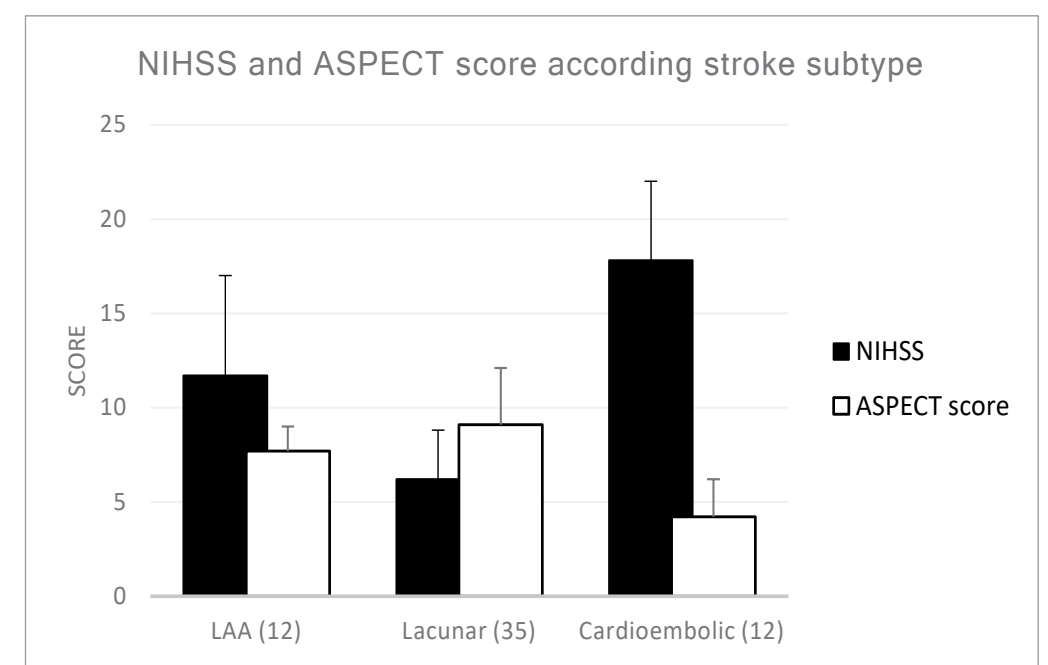

FIGURE 2. ASPECT score and NIHSS according stroke subtype

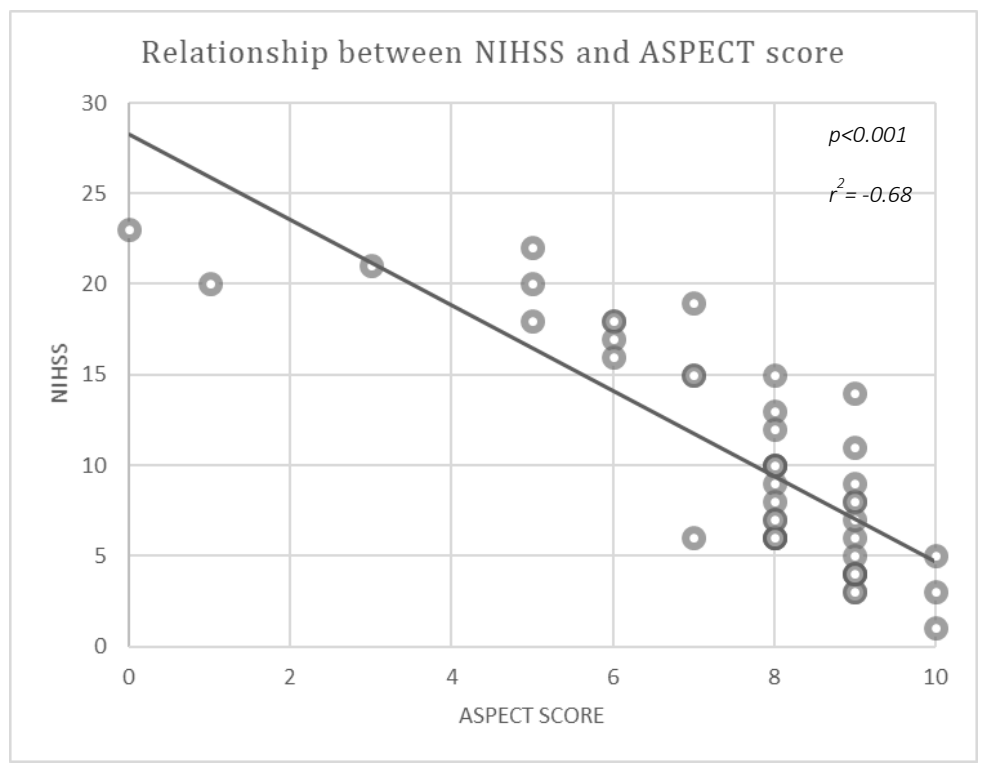

FIGURE 3. Correlation between ASPECT dan NIHSS score

\section{DISCUSSION}

Ischemic strokes occur as a result of an obstruction within a blood vessel supplying blood to the brain. Prompt treatment is crucial. Early action can minimize brain damage and potential complications (Alfa 2010; Hacke et al. 2004; Hill et al. 2005; Menon et al. 2011).

Imaging plays a key role in the management of acute ischemic stroke (AIS). Computed tomography (CT) is presently the imaging modality of choice for the evaluation of patients with AIS (Alfa 2010; Hacke et al. 2004; Hill et al. 2005; Menon et al. 2011).

The Alberta Stroke Programme Early CT Score (ASPECTS) is a simple and reproducible grading system developed to assess early ischemic changes in non-contrast computed tomography (NCCT) (Alfa 2010; Meschia et al. 2014; Puetz et al. 2009) and is currently used worldwide in the decision algorithm for thrombolysis and mechanical thrombectomy in anterior circulation AIS 
From our research, we found that LAA and lacunar stroke subtype have higher ASPECT and lower NIHSS than cardioembolic stroke. It means, higher ASPECT makes mild neurological deficit which had strong negative correlation with NIHSS. The severity of an ischemic stroke is determined by the ischemic location and the extent of the ischemic lesions that occur, but it is also determined by the patient's metabolic condition during a stroke (Glymour et al. 2007; Misbach \& Ali 2000).

Glymour et al. (2007) mentioned in their study that stroke with ischemic lesions located in the subcortical region had a NIHSS value lower than strokes with ischemic lesions in the cortical region (Arboix \& Alió 2010). The results of this study are supported by Horie et al. (2016) who also mentioned cardioembolic strokes have a higher NIHSS value (Kim \& Kim 2014). Blockages due to emboli usually occur in branching of arteries such as bifurcations from carotid internal arteries to cerebral arteries media and anterior sebaceous arteries, or at the bifurcation of the cerebral artery media. Emboli rarely clogs the penetratingartery in the media cerebral artery such as the lenticulostriate artery because this artery is almost perpendicular to the source artery (Kim \& Kim 2014). Lacunar stroke has a location in the subcortical region (basal ganglia) and has lesions that are much smaller than cardioembolic or stroke strokes LAA (Arboix \& Alió 2010; Glymour et al. 2007). The study by Heldner et al. (2013) stated that strokes with embolic blockages in the proximal region had a higher NIHSS value than strokes with distal blockages or strokes without blockages (Arboix \& Alió 2010). Proximal blockages occur in strokes caused by large emboli like emboli which comes from the heart.

The correlation coefficient between ASPECTS and NIHSS is -0.680 with a $p$ value of $<0.001$ which means there is a strong negative correlation between ASPECTS and NIHSS in acute ischemic stroke. The conclusion of this statistical analysis is that the high ASPECTS score in acute ischemic stroke has a low NIHSS value, and vice versa. This is in accordance with the results of the Canadian Alteplase for Stroke Effectiveness Study (CASES) study in Canada by Hill and Buchan (2005) which states that subjects with ASPECTS 6-10 grades have a higher likelihood of independent living.

Limitation of this study, we did not perform CT perfusion or Magnetic Resonance Imaging Diffusion Weightened Imaging to compare infarct volume from infarct core with non-contrast brain CT. In developing country, such as Indonesia, CT perfusion and Magnetic Resonance Imaging Diffusion Weightened Imaging were not routine examination on acute ischemic stroke patients because of limitation modalities in emergency room. According to this study, we hope that ASPECT can be used by more neurologist to predict infarct core on acute ischemic stroke patient whenever CT perfusion or Magnetic Resonance Imaging Diffusion Weightened Imaging are not available.

\section{CONCLUSION}

There was a strong inverse correlation between ASPECTS and NIHSS score on acute ischemic stroke. The higher the value ASPECTS, it will be the lower value of the NIHSS and ASPECT score.

\section{REFERENCES}

Alfa, A.Y. 2010. Penatalaksanaan Stroke Fase Akut. In Neurology in Daily Practice, edited by Basuki, A. \& Dian, S. 1st ed. Bandung: Bagian/UPF Ilmu Penyakit Saraf Fakultas Kedokteran UNPAD/RS. Hasan Sadikin. pp. 67-84.

Arboix, A. \& Alió, J. 2010. Cardioembolic stroke: Clinical features, specific cardiac disorders and prognosis. Current Cardiology Reviews 6(3): 150-161.

Glymour, M.M., Berkman, L.F., Ertel, K.A., Fay, M.E., Glass, T.A. \& Furie, K.L. 2007. Lesion characteristics, NIH stroke scale, and functional recovery after stroke. American Journal of Physical Medicine \& Rehabilitation 86(9): 725 733.

Hacke, W., Donnan, G., Fieschi, C., Kaste, M., von Kummer, R., Broderick, J.P., Brott, T., Frankel, M., Grotta, J.C., Haley, E.C., Kwiatkowski, T., Levine, S.R., Lewandowski, C., Lu, M., Lyden, P., Marler, J.R., Patel, S., Tilley, B.C., Albers, G., Bluhmki, E., Wilhelm, M., Hamilton, S., ATLANTis Trials Investigators. \& ECASS Trials Investigators. 2004. Association of outcome with early stroke treatment: Pooled analysis of ATLANTIS, ECASS, and NINDS rt-PA stroke trials. Lancet 363(9411): 768-774.

Hill, M.D. \& Buchan, A.M. 2005. Thrombolysis for acute ischemic stroke: Results of the Canadian alteplase for Stroke Effectiveness Study. Canadian Medical Association Journal 172(10): 1307-1312.

Horie, N., Tateishi, Y., Morikawa, M., Morofuji, Y., Hayashi, K., Izumo, T., Tsujino, A., Nagata, I. \& Matsuo, T. 2016. Acute stroke with major intracranial vessel occlusion: Characteristics of cardioembolism and atherosclerosisrelated in situ stenosis/occlusion. Journal of Clinical Neuroscience 32: 24-29.

Kim, B.J. \& Kim, J.S. 2014. Ischemic stroke subtype classification: An Asian viewpoint. Journal of Stroke 16(1): 8-17.

Mansour, O.Y., Megahed, M.M. \& Abd Elghany, E.H.S. 2015. Acute ischemic stroke prognostication, comparison between Glasgow Coma Score, NIHS scale and full outline of unresponsiveness score in intensive care unit. Alexandria Journal of Medicine 51(3): 247-253.

Menon, B.K., Puetz, V., Kochar, P. \& Demchuk, A.M. 2011. ASPECTS and other neuroimaging scores in the triage and prediction of outcome in acute stroke patients Neuroimaging Clinics of North America 21(2): 407-423.

Meschia, J.F., Bushnell, C., Boden-Albala, B., Braun, L.T., Bravata, D.M., Chaturvedi, S., Creager, M.A., Eckel, R.H., Elkind, M.S., Fornage, M., Goldstein, L.B., Greenberg, S.M., Horvath, S.E., Iadecola, C., Jauch, E.C., Moore, W.S \& Wilson, J.A. 2014. Guidelines for the primary prevention of stroke. A statement for healthcare professionals from the American Heart Association/American Stroke Association. Stroke 45(12): 3754-3832.

Misbach, J. \& Ali, W. 2000. Stroke in Indonesia: A first large prospective hospital-based study of acute stroke in 28 hospitals in Indonesia. Journal of Clinical Neuroscience 8(3): 24524-24529. 
Puetz, V., Dzialowski, I., Hill, M.D. \& Demchuk, A.M. 2009. The Alberta Stroke Program early CT score in clinical practice: What have we learned? International Journal of Stroke 5: 354-364.

Lisda Amalia*, Marda Arif Furqani \& Ahmad Rizal Department of Neurology

University of Padjadjaran/Hasan Sadikin

General Hospital Bandung

Indonesia

Ida Parwati

Department of Clinical Pathology

University of Padjadjaran/Hasan Sadikin

General Hospital Bandung

Indonesia
Ramdan Panigoro

Department of Basic Medical Science

University of Padjadjaran/Hasan Sadikin

General Hospital Bandung

Indonesia

*Corresponding author; email: dr.lisda@gmail.com

Received: 17 September 2018

Accepted: 21 January 2020 